Jarosław FILIPIAK ${ }^{1}$, Jacek SADOWSKI ${ }^{2}$, Rajmund TRZEBIATOWSKI ${ }^{2}$, Antoni PRZYBYE ${ }^{3}$,

Fish aquaculture

\title{
EFFECT OF DIFFERENT LEVELS OF DIETARY LIPIDS \\ IN EXTRUDED FEEDS ON THE REARING RESULTS OF CARP FRY (CYPRINUS CARPIO L.) CULTURED IN COOLING WATER WPEYW RÓŻNEJ ZAWARTOŚCI LIPIDÓW W PASZACH EKSTRUDOWANYCH NA EFEKTY CHOWU NARYBKU KARPIA (CYPRINUS CARPIO L.) W WODZIE POCHLODNICZEJ
}

\author{
${ }^{1}$ Department of Fisheries Management in Inland Waters, Agricultural University of Szczecin, \\ Poland \\ ${ }^{2}$ Department of Aquaculture, Agricultural University of Szczecin, Poland \\ ${ }^{3}$ Department of Inland Fishery and Aquaculture, Agricultural University of Poznań, Poland
}

\begin{abstract}
Carp of the initial individual weight of $30 \mathrm{~g} / \mathrm{ind}$. $( \pm 5 \mathrm{~g}$ ) were fed for 83 days with three kinds of extruded, isoprotein (47.5\%) feeds differing in the lipid content $(9.1 \%$, in feed $\mathrm{A}$, $12.9 \%$ in feed $\mathrm{B}$, and $17.0 \%$ in feed $\mathrm{C}$ ). The main source of the lipids was a poultry fat. After the completion of the experiment the following values of the Specific Growth Rate, SGR index were achieved (respectively): $2.45,2.75,2.59 \%$ The values of Food Conversion Ratio, FCR were as follows: 1.27, 1.10, 1.21, while the Energy Retained index was respectively: 23.7, 29.6 , and $26.6 \%$. In the present experiment consisting in feeding the carp fry in the conditions of cooling water at 13.1$31.2^{\circ} \mathrm{C}$, the most favourable results of rearing were achieved using the extruded feed containing $12.9 \%$ of lipids. The lipids consisted of $2 / 3$ of poultry fat and $1 / 3$ of structural fish fat.
\end{abstract}

\section{INTRODUCTION}

In carp feeding, as well as in the feeding of other fishes, a significant role in obtaining a quick weight increment is played by lipids present in the feeds supplied. Considering their specific chemical structure-lipids in comparison with proteins and carbohydrates constitute a more effective (by 1.9 and 2.4 times) source of the metabolic energy for carp (Smith 
1971; Chiou and Ogino 1975; Austreng 1978). Besides the energetic aspect, however, fast growth of carp can be assured by including in the feeds such lipid components, which contain respectively high level of exogenous n-3 and n- 6 fatty acids (Takeuchi and Watanabe 1977). One of them — characterized by a high level of linoleic acid (18:2 n-6) - is the poultry fat obtained as a by-product in the process of manufacturing the poultry meal form the postslaughter leftovers (Viola and Amidan 1978). A number of feeding experiments conducted in rather specific conditions of cooling water (Filipiak 1989, 1995; Filipiak and Trzebiatowski 1992) demonstrated a distinct enhancement of the carp fry growth, after supplementing the feeds with poultry feed. It has to be mentioned, that the feeds used in the above experiments, due to the production method used (granulation—currently going out of use) had relatively high (1.5-2.0) values of the food conversion ratios.

The aim of the present study was evaluation of the effect of different levels of poultry fat in the feeds manufactured through extrusion process, on the growth and other indices of the rearing process of carp kept in cooling water.

\section{MATERIAL AND METHOD}

The nutritional study was conducted from 20 July to 20 October 1994 in the Fisheries Experimental Station (RSD), located near the "Dolna Odra" power plant at Nowe Czarnowo, and owned by the Department of Aquaculture, Agricultural University of Szczecin. The experimental material consisted of carp fry of the average individual body weight of $30 \mathrm{~g}( \pm 5 \mathrm{~g})$. The fish acquired as hatchlings in early June were reared up to the individual weight of $7 \mathrm{~g}$ in GRSP Gosławice in ponds and tanks supplied with cooling water. Subsequently form 5 July 1994 to the beginning of the proper experiment the fish were kept in the cages of the RSD. Nine cages were used to accommodate the fish during the study period. The dimensions of each cage were as follows: $0.75 \times 2.0 \times 0.8 \mathrm{~m}$, while its practical volume was $1 \mathrm{~m}^{3}$. The cages were stocked with 125 fish each.

The experimental carp were fed daily with three feeds marked with the symbols A, B, C, differing in the lipid content (Tab. 1). Each of the feeds was tested in three repetitions (Tab. 1). The feeds were manufactured using an extrusion method at the Experimental Facility of the Department of Food Technology and Aquaculture of the University of Agriculture at Poznań. Identical rations of each feed, calculated (Filipiak et al. 1995a) in relation to the metabolic weight of the fish $\left(\mathrm{W}^{0.8}\right)$ were: $2.5 \%$ from 29 July to 17 August, $2.25 \%$ from 18 August to 28 September, and 1.0\% from 29 September till the end of the experiment. Within the initial two weeks of the study the fish were fed with the pellet feed of the same diameter of the pellets $-2 \mathrm{~mm}$. Within the next two weeks the diameter increased up to $3 \mathrm{~mm}$, to reach $5 \mathrm{~mm}$ in the reminder of the experiment. 
Table 1

Components and chemical composition (\%) of diets used for feeding carp fry (0+)

\begin{tabular}{|c|c|c|c|}
\hline \multirow{2}{*}{ Components } & \multicolumn{3}{|c|}{ Experimetal treatment } \\
\hline & $\mathrm{A}$ & $\mathrm{B}$ & $\mathrm{C}$ \\
\hline Fish meal & 36.0 & 36.0 & 36.0 \\
\hline Poultry by product meal & 26.0 & 26.0 & 26.0 \\
\hline Yeast (Torula) & 9.0 & 9.0 & 9.0 \\
\hline Wheat meal & 16.7 & 12.7 & 10.7 \\
\hline Poultry fat & 0.5 & 4.5 & 8.5 \\
\hline Wheat bran & 10.0 & 10.0 & 8.0 \\
\hline Polfamix $\mathrm{W}^{*}$ (commercial vitamin mixture) & 1.1 & 1.1 & 1.1 \\
\hline Rapeseed lecithine & 0.5 & 0.5 & 0.5 \\
\hline Choline chloride & 0.2 & 0.2 & 0.2 \\
\hline \multicolumn{4}{|l|}{ Chemical composition } \\
\hline Dry matter & 93.8 & 93.9 & 94.9 \\
\hline Crude protein $(\mathrm{P})$ & 47.6 & 47.5 & 47.5 \\
\hline Lipids & 9.1 & 12.9 & 17.0 \\
\hline Ash & 9.9 & 9.9 & 9.7 \\
\hline Fiber & 1.1 & 0.9 & 1.1 \\
\hline $\mathrm{N}$-free extract & 26.1 & 22.6 & 19.7 \\
\hline Gross energy $(\mathrm{E})(\mathrm{KJ} / \mathrm{g})$ & 19.6 & 20.8 & 21.6 \\
\hline $\mathrm{P} / \mathrm{E}$ & 24.3 & 22.8 & 22.0 \\
\hline
\end{tabular}

* 1 kg contains: Vitamin: A-10000 IU, D -2000 IU, E-1.5 g, K-0.2 g, B -0.05 g, $\mathrm{B}_{2}-0.4 \mathrm{~g}, \mathrm{~B}_{12}-0.001 \mathrm{~g}$, nicotinic acid-2,5 g, pantothenian $\mathrm{Ca}-1.0 \mathrm{~g}$, choline chloride-7.5 g, folic acid-0.1 g, methionine $-150 \mathrm{~g}$, lysine $-150 \mathrm{~g}, \mathrm{Fe}-2.5 \mathrm{~g}, \mathrm{Mn}-6.5 \mathrm{~g}$, $\mathrm{Cu}-0.8 \mathrm{~g}, \mathrm{Co}-0.04 \mathrm{~g}, \mathrm{Zn}-4.0 \mathrm{~g}, \mathrm{~J}-0.08 \mathrm{~g}$.

On the beginning and at the end of each experiment, a total of 6 fish was sampled from each experimental treatment. They were subjected to a complete homogenisation and examined for the content of: dry mass (drying for 12 hours at $105^{\circ} \mathrm{C}$ ), crude protein (Kjeltec 1026), lipids (Soxhlet method; 12 hours of extraction with ethyl ether), ash (combustion at $550^{\circ} \mathrm{C}$ for 12 hours). The chemical analyses of the feeds were conducted using the same methods, however the content of $\mathrm{N}$-free extract was determined from the difference between the dry mass and the sum of the remaining components, including the fiber. The content of the latter component was determined using a standard method of acid and base hydrolysis. The level of the gross energy in the feeds was determined from the individual components using the following conversion coefficients: 39.53 (lipids), 23.63 (crude protein), and $17.15 \mathrm{~kJ} / \mathrm{g}$ (carbohydrates) (Jobling 1994).

To asses the dynamics of the changes in the basic rearing indices and to adjust the amounts of the administered feed to the current needs, the fish were weighed to the nearest $0.05 \mathrm{~kg}$ in each cage every 6-7 days. The results of the control weighing the stage values of 
the following coefficients were determined: FCR (Food Conversion Ratio), SGR (Specific Growth Rate), aNPU (apparent Net Protein Utilisation), ER (Energy Retained), and aLR (apparent Lipids Retained). To determine the significance of the differences between the experimental treatments all values of the above-mentioned rearing coefficients were subjected to statistical analysis (LSD test, $P=0.05$ ).

The temperature, oxygen content, and $\mathrm{pH}$ of the cooling water were constantly monitored (every 60 minutes), using an automated recorder. The mean diel values and the ranges of changes of the analysed physical-chemical parameters are shown on Fig. 1.

\section{RESULTS AND DISCUSSION}

\section{Description of the experimental feeds}

The appropriate composition of the feeds resulted in equal content of crude protein in all feeds. The crude protein there amounted to $47 \%$. Such level was only slightly (by 2.5 percentage points) higher than the quantitative demand of the carp fry for this nutritive component, as recommended for intensive rearing of this fish in cooling water within the temperature range of $25-30^{\circ} \mathrm{C}$ (Filipiak 1995). Diverse levels of lipids (Feed A-9.1\%; B-12.9\%; C-17.0\%) were a consequence of variable amounts of semi-liquid poultry fat added to the feeds in the production process (Tab. 1). The basic level of fats in all feeds, amounting to $8.6 \%$, represented the structural fats present in some components. The latter contained the following amounts of lipids: fish meal- $11.2 \%$, poultry by-product meal$15.5 \%$, and rapeseed lecithin- $0.5 \%$. Rapeseed lecithin was added to the feeds in the optimal for the carp fry quantities, as an emulsifier of lipids (Sadowski et al. 1997). The poultry fat content related to the total fat content, assumed as $100 \%$, was $49.7 \%$ in feed $\mathrm{A}$, $66.1 \%$ in feed $\mathrm{B}$, and $73.7 \%$ in feed $\mathrm{C}$.

\section{Environmental conditions}

Throughout the entire experiment the values of the studied physical-chemical parameters of the post-cooling water discharged by the "Dolna Odra" power plant exhibited extensive variability typical for the summer-fall season (Filipiak et al. 1995). The average diel water temperatures fluctuated within the range of $13.1-31.2^{\circ} \mathrm{C}$. The oxygen content changed within $2.9-12.2 \mathrm{mg} / \mathrm{dm}^{3}$, while the $\mathrm{pH}$ was relatively stable and it ranged from 8.1 to 9.1 (Figs. 1a, b, c). The data, to facilitate their interpretation, were grouped in three periods differing in the temperature of the cooling water. The first one, with a high water temperature ranging from $23.7-31.2^{\circ} \mathrm{C}\left(29.0^{\circ} \mathrm{C}\right.$ in average) lasted from 29 July to 17 August (Fig. 1a). The second period, lasting from 8 August to 28 September had the mean diel water temperature of $23.9^{\circ} \mathrm{C}\left(20.0-25.6^{\circ} \mathrm{C}\right.$ range). The last-fall period, lasting from 29 September to 20 October, was the coolest, with the average of $15.8^{\circ} \mathrm{C}\left(19.8-13.1^{\circ} \mathrm{C}\right)$. 


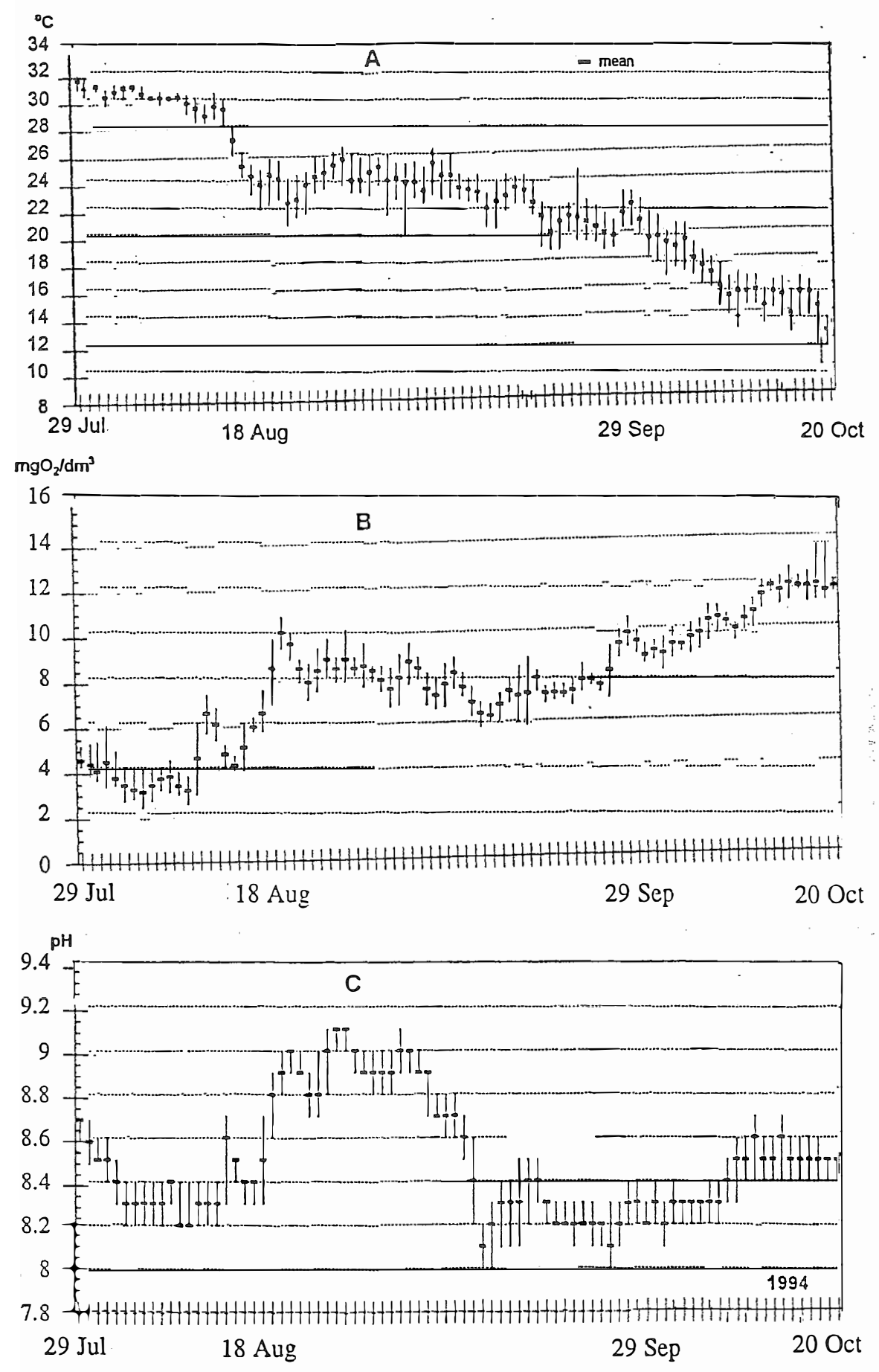

Fig. 1. Diel changes of temperature (A), oxygen contents (B), and $\mathrm{pH}(\mathrm{C})$ in cooling water during the experiment 
Rearing results

Table 2

Mean individual weight of carp, Specific Growth Rate (SGR) and Food Conversion Ratio (FCR) in each part of experiment

\begin{tabular}{|c|c|c|c|c|}
\hline \multirow{3}{*}{$\begin{array}{l}\text { Experimental } \\
\text { treatments (\% of } \\
\text { lipids in feed) }\end{array}$} & \multicolumn{4}{|c|}{ Dates of fish weighing } \\
\hline & $29 \mathrm{Jul}$ & 18 Aug & 29 Sep & 20 Oct \\
\hline & \multicolumn{4}{|c|}{ Mean individual weight (g) } \\
\hline A $(9.1)$ & 31.6 & 62.9 & 190.8 & 241.7 \\
\hline B (12.9) & 29.9 & 64.7 & 222.0 & 293.3 \\
\hline $\mathrm{C}(17.0)$ & 29.9 & 62.4 & 204.5 & 256.9 \\
\hline \multicolumn{5}{|c|}{ SGR } \\
\hline A & - & $3.28^{\mathrm{b}}$ & $2.64^{\mathrm{b}}$ & $1.13^{\mathrm{b}}$ \\
\hline B & - & $3.68^{\mathrm{a}}$ & $2.94^{\mathrm{a}}$ & $1.33^{\mathrm{a}}$ \\
\hline $\mathrm{C}$ & - & $3.50^{\mathrm{a}}$ & $2.83^{\mathrm{a}}$ & $1.09^{\mathrm{b}}$ \\
\hline & SE & 0.04 & 0.03 & 0.02 \\
\hline \multicolumn{5}{|c|}{ FCR } \\
\hline A & - & $1.22^{\mathrm{b}}$ & $1.24^{\mathrm{c}}$ & $1.36^{\mathrm{b}}$ \\
\hline B & - & $1.08^{\mathrm{a}}$ & $1.10^{\mathrm{a}}$ & $1.12^{\mathrm{a}}$ \\
\hline $\mathrm{C}$ & - & $1.16^{\mathrm{b}}$ & $1.16^{\mathrm{b}}$ & $1.40^{\mathrm{b}}$ \\
\hline & SE & 0.02 & 0.01 & 0.02 \\
\hline Daily food ration & $\left(\% \mathrm{~W}^{0.8}\right)$ & 2.50 & 2.25 & 1.00 \\
\hline
\end{tabular}

It is evident from analysis of the results given in $\mathrm{Tab}$. 2 and Fig. 1a that despite the different temperatures of the cooling water in the respective stages of the study, that in each case the lowest food conversion ratio (FCR) was achieved on feed $\mathrm{B}$ containing $12.9 \%$ of lipids of which $2 / 3$ constituted poultry fat. Compared to the FCR value obtained in treatment B (assumed as $100 \%$ ) the values of treatment A were respectively higher by 12.9, 12.7, and $21.4 \%$, while in treatment $\mathrm{C}$-by $7.4,5.4$, and $25.0 \%$. It is well visible from the above results, that in the last period of the study (29 September-20 October), despite the downsizing of the daily ration of the tested feed to $1 \% \mathrm{~W}^{0} 8$, the consumption of the feed to a weight unit of the fish, described by FCR coefficient, increased only in treatments A and C. This fact suggests unfavourable effect of both deficiency and oversupply of lipids present in the extrude feeds, on the efficiency of their use for large carp fry reared in relatively low temperature of cooling water (it declined from 19.8 to $13.1^{\circ} \mathrm{C}$ ). The other studies, however, conducted with carp fry in similarly low temperature of cooling water, using traditional pellet feeds of diverse content of poultry fat, did not bring any significant differences in FCR coefficients (Filipiak and Trzebiatowski 1992). Taking this into account, the earlier suggestion, raised in the present paper must be reconfirmed by additional comparative studies. It must be also emphasised, that the distinct variability of the physical-chemical parameters of the cooling water and also the diverse lipid levels in the feeds did not affect the survivability of the carp stocks. It was maintained in all cages at the level of $100 \%$, as determined from the final effect of the rearing. Despite the decreasing metabolism over the duration of the experiment, caused not only by the increment of the individual weight of the fish, but also by the decreasing temperature of the cooling water, the carp by the and of 83-day-long rearing, achieved relatively high values of the individual weight, ranging from $241.7 \mathrm{~g}$ in 
experimental treatment A to $293.3 \mathrm{~g}$ in treatment B. The achievement of 8-10-fold weight increment in such relatively short time indicates the existence of favourable environmental conditions and a substantial growth potential of the carp fry. The latter potential reveals itself while the fish are fed with extruded feeds containing appropriately high levels of crude protein and gross energy. A forcible confirmation of the above regularity are the study results of Sadowski et al. (1998) who achieved 12-fold increase of the individual body weight as fast as after 35 days. The rearing was carried out in conditions of cooling water, using a similar as in the present study stocking material (carp, $21 \mathrm{~g}$ of individual weight). The fish were fed for 18 hours a day with a commercial extruded trout feed containing, among other components: $45 \%$ of protein and $22 \mathrm{KJ} / \mathrm{g}$ of energy. The final individual weight was $244 \mathrm{~g}$.

Statistical analysis of the present results shown in Tab. 3 revealed that experimental treatment $\mathrm{B}$, compared to treatments $\mathrm{A}$ and $\mathrm{C}$ had distinctly higher values of the following indices: apparent Net Protein Utilisation (aNPU), apparent Lipids Retained (aLR), and Energy Retained (ER). It is important that the fish from all treatments did not differ significantly in the crude protein content. No significant differences in the lipid content were observed between treatments B and C (Tab. 4). It means that the highest values of the retention indices in treatment $\mathrm{B}$ did not depend on the protein-and lipid content in the fish bodies, but most probably it resulted from a better absorption of the feed containing $12.9 \%$ of lipids and $20.8 \mathrm{KJ} / \mathrm{g}$ of energy. It can be also indirectly confirmed by more favourable SGR and FCR indices (Tab. 3).

Table 3

Specific Growth Rate (SGR), Food Conversion Ratio (FCR), apparent Net Protein Utilization (aNPU), apparent Lipid Retained (LR) and Energy Retained (ER) of carp fry $(0+)$ fed different level lipids in feed after 83 days of experiment

\begin{tabular}{|c|c|c|c|c|c|}
\hline $\begin{array}{c}\text { Experimental treatments } \\
\text { (\% of lipids in feed) }\end{array}$ & $\begin{array}{c}\text { SGR }^{1} \\
(\% / \text { day) }\end{array}$ & FCR $^{2}$ & $\begin{array}{c}\mathrm{aNPU}^{3} \\
(\%)\end{array}$ & $\begin{array}{c}\mathrm{aLR}^{4} \\
(\%)\end{array}$ & $\begin{array}{c}\mathrm{ER}^{\mathrm{s}} \\
(\%)\end{array}$ \\
\hline $\mathrm{A} \mathrm{(9.1)}$ & $2.45^{\mathrm{c}}$ & $1.27^{\mathrm{c}}$ & $26.2^{\mathrm{c}}$ & $63.7^{\mathrm{b}}$ & $23.7^{\mathrm{c}}$ \\
$\mathrm{B}(12.9)$ & $2.75^{\mathrm{a}}$ & $1.10^{\mathrm{a}}$ & $29.7^{\mathrm{a}}$ & $64.8^{\mathrm{a}}$ & $29.6^{\mathrm{a}}$ \\
C (17.0) & $2.59^{\mathrm{b}}$ & $1.21^{\mathrm{b}}$ & $27.3^{\mathrm{b}}$ & $51.4^{\mathrm{c}}$ & $26.6^{\mathrm{b}}$ \\
\hline SE & 0.02 & 0.01 & 0.19 & 0.03 & 0.19 \\
\hline
\end{tabular}

${ }^{1}$ - defined as a different between $\ln$ of final and initial individual weight of fish divided by time $\times 100$,

2 - total food ration per unit of fish weight gain,

3 - amount of crude protein retained per unit of crude protein intake $\times 100$,

${ }^{4}$ - amount of lipids retained per unit of lipids intake $\times 100$,

5 - amount of gross energy retained per unit of gross energy intake $\times 100$ 
Table 4

Chemical body composition (\%) of carp fry $(0+)$ at the start and the end of experiment

\begin{tabular}{|c|c|c|c|c|}
\hline $\begin{array}{c}\text { Experimental treatments } \\
\text { (\% of lipids in feed) }\end{array}$ & Dry matter & Crude protein & Lipids & Ash \\
\hline \multicolumn{4}{|c|}{ Start of experiment } \\
\hline \multicolumn{5}{|c|}{ End of experiment } \\
\hline A (9.1) & 21.4 & 13.0 & 6.6 & 1.6 \\
\hline B (12.9) & $25.5^{\mathrm{b}}$ & $15.4^{\mathrm{a}}$ & $5.9^{\mathrm{a}}$ & $2.0^{\mathrm{a}}$ \\
C (17.0) & $26.0^{\mathrm{b}}$ & $15.2^{\mathrm{a}}$ & $8.0^{\mathrm{b}}$ & $2.2^{\mathrm{a}}$ \\
\hline SE & 0.09 & $15.4^{\mathrm{a}}$ & $8.4^{\mathrm{b}}$ & $2.1^{\mathrm{a}}$ \\
\hline
\end{tabular}

It seems that among the factors potentially giving advantage to treatment $\mathrm{B}$ in the respect of the discussed above rearing factors were: the appropriate (to the needs of carp) gross energy level in the feed and the fact that it contained the appropriate amount of poultry fat, providing exogenous fatty acids, linolenic acid in particular. Based on the data of Viola and Amidan (1978) regarding the content of linoleic- (18:2 n-6) and linolenic (18:3 $\mathrm{n}-3$ ) acid in poultry fat ( $23 \%$ and $3 \%$ respectively) and in fish oil (1\% and $1 \%$ respectively) a probable content of these components in the feeds tested in the present experiment was determined. The feeds in the respective treatments contained the following amounts of linoleic (and linolenic) acids: $\mathrm{A}-1.08 \%(0.18 \%), \mathrm{B}-2.00 \%(0.26 \%)$, and $\mathrm{C}-2.92 \%$ $(0.34 \%)$. Assuming after Takeuchi and Watanabe (1977) the requirement of carp for linoleic acid as $1.0 \%$ we can see that all the feeds contained higher amounts of this acid that its minimal value. In the calculations, however, no consideration was given to a fact that the absorption of fat (as well as fatty acids) decreases as an effect of high temperatures used in the process of feed extrusion. It is also evident from the study results of the abovementioned authors, that not only deficiencies of linoleic acid, but also its oversupply in a diet can limit the growth rate of carp. Taking this into account it seems reasonable, that the feed of treatment B contained appropriate to the needs level of linoleic acid. This feed gave the most favourable rearing results. As for the quantitative requirements of carp for linolenic acid, there has been a substantial disagreement (Takeuschi and Watanabe 1977; Viola and Amidan 1978; Neto at al. 1993; Sargent at al. 1995). In view of the above, attempts on unambiguous determination which of the feeds contained the appropriate amount of this exogenous component would be inadvisable. Considering, however, relatively high growth rate of the fish, attained along with low nutritive indices, it seems evident that in all feeds tested, the calculated content of linolenic acid most probably fulfilled carp requirements for this exogenous component. 


\section{CONCLUSIONS}

1. The results of the present rearing experiment, conducted in the conditions of cooling water of variable temperature, confirmed suitability-of high-protein extruded feeds containing poultry fat lipids for feeding carp fry.

2. The most favourable SGR and FCR indices and the highest apparent Net Protein Utilisation (aNPU) and apparent Lipid Retention were obtained while feeding the carp fry with a feed containing $12.9 \%$ of lipids in a form of fish oil and poultry fat in the proportion of $1: 2$.

\section{ACKNOWLEDGEMENTS}

This research work had been carried out in the frames of the project No. 5 S311 001 05, financed in the years of 1993-1995 by the State Committee for Scientific Research $(\mathrm{KBN})$.

\section{REFERENCES}

Austreng $\mathbb{E}$., 1978: Digestibility determination in fish using chromic oxide marking and analysis of contents of different segments of the gastrointestinal tract. Aquaculture, 13: 256-272.

Chiou J.Y., Ch. Ogino, 1975: Digestibility of starch in carp, Bull. Jap. Soc. Sci Fish., 41 (4): $465-$ 466.

Filipiak J., 1989: Wykorzystanie mączki mięsno-kostnej i thuszczu drobiowego w żywieniu narybku karpia $(\mathrm{Kw}-1) \mathrm{w}$ warunkach wody pochłodniczej [Utilization of poultry byproduct meal and poultry fat on feeding young carp reared in cooling water]. Gospod. Ryb., 4: 14-16. (In Polish).

Filipiak J., 1995: Wybrane aspekty żywienia karpi (Cyprinus carpio L.) w sadzowym chowie $\mathrm{w}$ wodzie pochłodniczej [Selected aspects of feeding the carp Cyprinus carpio L. kept in heated-water cage cultures]. Zesz. Nauk. AR w Szczecinie, ser. Rozprawy nr 167 (DSc Thesis) (In Polish with English abstract).

Filipiak J., R. Trzebiatowski, 1992: Wpływ mieszanek paszowych wzbogaconych o różne rodzaje thuszczów na podstawowe wskaźniki chowu narybku karpi w wodzie pochłodniczej [Effect of feed mixtures enriched with various fats on basic indices of young carp reared in cooling waters.] Zesz. Nauk. AR Wrocław, 218: 81-88 (In Polish with English abstract).

Filipiak J, R. Trzebiatowski, J. Sadowski, 1995: Rybactwo cz. II - wybrane elementy chowu ryb. [Fisheries-selected aspects of fish culture]. Wyd. AR w Szczecinie, Szczecin. (In Polish).

Jobling M., 1994: Fish bioenergetics. Ed. Chapman \& Hall, London.

Neto R.J, G. Corraze, N. Charlon, P. Bergot, 1993: Essential n-3 fatty acid requirements of carp (Cyprinus carpio) larvae. In: From Discovery to commercialization. Abstracts of contributions presented at the International Conference-Torremolinos, Spain, May 26-28, 1993: 187.

Sadowski J., J. Filipiak, R. Trzebiatowski, 1997: Impact of different levels of rapeseed lecithin in diet on effects of rearing of carp (Cyprinus carpio L.) in cooling water. Zesz. Nauk. AR Szczecin, 179: 35-42. 
Sadowski J., J. Filipiak, R. Trzebiatowski, 1998: Effect of different duration of feeding on results of carp (Cyprinus carpio L.) fry cage culture in cooling water. Electronic Journal of Polish Agricultural Universities (EJPAU), 1, 1: 1-10.

Sargent J.R., J.G. Bell, M.V. Bell, R.J. Henderson, D.R. Tocher, 1995: Requirement criteria for essential fatty acids. J. Appl. Ichthyol., 11: 183-198.

Smight R.R, 1971: A method for measuring the digestibility and metabolisable energy of fish feeds. Progr. Fish Culturist, 33: 132-134.

Takeuchi T., T. Watanabe, 1977: Requirement of carp for essential fatty acids. Bull. Jap. Soc. Sci. Fish., 43: 541-551.

Viola S., G. Amidan, 1978: The effects of different dietary oil supplements on the composition of carp's body fat. Bamidgeh, 30 (4): 104-109.

Jarosław FILIPIAK, Jacek SADOWSKI, Rajmund TRZEBIATOWSKI, Antoni PRZYBYE

\section{WPŁYW RÓŻNEJ ZAWARTOŚCI LIPIDÓW W PASZACH EKSTRUDOWANYCH NA EFEKTY CHOWU NARYBKU KARPIA (CYPRINUS CARPIO) W WODZIE POCHEODNICZEJ}

\section{STRESZCZENIE}

Narybek karpi o masie $30 \mathrm{~g} / \mathrm{szt}$. ( $\pm 5 \mathrm{~g}$ ) obsadzone po 125 sztuk do 9 sadzów o objętości użytkowej $1 \mathrm{~m}^{3}$ (po trzy sadze na każdy wariant), przez 83 dni żywiono trzema ekstrudowanymi paszami charakteryzującymi się taką samą zawartością białka ogólnego $(47,5 \%)$ oraz różnym poziomem lipidów (wariant $\mathrm{A}-9,1 ; \mathrm{B}-12,9$ i $\mathrm{C}-17,0 \%$ ). Zróżnicowanie zawartości lipidów uzyskano $\mathrm{w}$ wyniku dodawania $\mathrm{w}$ procesie produkcji pasz różnej ilości thuszczu drobiowego, odpowiednio w wariancie A - 0,5; w B - 4,5 i C - 8,5\%. Doświadczenie żywieniowe prowadzono w okresie lata i jesieni, w temperaturze wody zmieniającej się w zakresie od 13,1 do $31,2^{\circ} \mathrm{C}$.

Uzyskane po zakończeniu badań wartości wskaźnika dobowego przyrostu średniej masy jednostkowej karpi - SGR (wariant A - 2,45; B - 2,75 i C - 2,59\%/dobę) oraz współczynnika pokarmowego - FCR (odpowiednio 1,27; 1,10 i 1,21), jak również wskaźnika pozornej retencji białka ogólnego - aNPU (26,2; 29,7 i 27,3\%) oraz retencji energii - ER (odpowiednio: 23,7; 29,6 i 26,6\%) wskazuja, że najkorzystniejsze efekty chowu uzyskano na paszy zawierającej m.in. $20,8 \mathrm{KJ} / \mathrm{g}$ energii brutto oraz $12,9 \%$ lipidów, w których $2 / 3$ stanowil thuszcz drobiowy, a $1 / 3$ - strukturalny, zawarty w mączce rybnej, tłuszcz rybny.

Author's address:

Jarosław Filipiak PhD DSc

Department of Fisheries Management in Inland Waters

Agricultural University of Szczecin

Kazimierza Królewicza 4, 71-550 Szczecin, Poland 